\title{
NEPHROTIC SYNDROME FOLLOWING SODIUM BISMUTH TARTRATE THERAPY IN RHEUMATOID ARTHRITIS
}

BY

\author{
J. W. BEATTIE \\ Department of Clinical Medicine, University of Leeds
}

(RECEIVED FOR PUBLICATION JANUARY 9, 1953)

Parenteral therapy with sodium bismuth tartrate has now been undertaken in rheumatoid arthritis for some time. This salt, according to Martindale (Vol. $2,1943)$, is a white powder or yellowish scale preparation containing $35-42$ per cent. bismuth. Its general safety can be deduced from the report of Goodman (1948) that almost $\frac{1}{4}$ ton, representing more than $1 \frac{1}{2}$ million adult doses, had been administered in the Gold Coast between 1933 and 1942 with no recorded fatalities. The following case is considered worthy of report as an example of fatal renal damage caused by the drug, which was administered in the usual therapeutic dosage.

\section{Case Report}

A housewife, aged 39, was seen at the out-patient department of another hospital on March 9, 1949, com- plaining of recurrent pain and swelling of the hands, $\bar{\varrho}$ elbows, shoulders, feet, knees, and neck of 4 to 5 months' $\vec{N}$ duration. She also complained of weakness, fatigue, and is listlessness. Examination showed that her general con- $\vec{A}$ dition was fairly good, but she was rather anaemic. The $\stackrel{A}{+}$ affected joints showed the changes of rheumatoid arth- 을 ritis; there was some fluid in both knee joints. No other abnormalities were noted. Blood count showed a normo- $c$ chromic anaemia (Table). The erythrocyte sedimentation $\subsetneq$ rate (Wintrobe) was $55 \mathrm{~mm}$./1 hr. A catheter specimen of ${ }^{\varnothing}$ urine showed a trace of albumin, a deposit containing $\overrightarrow{0}$ 15-20 pus cells, and an occasional red cell per high-power $\mathcal{W}$ microscopic field, but no casts or crystals.

On July 14, after a long course of physiotherapy, the first injection of sodium bismuth tartrate $0.5 \mathrm{gr}$. in $0.5 \mathrm{ml}$. was given, and she received four further fortnightly $\overline{0}$ injections, the last apparently on September 9 . The joints $\stackrel{2}{\not}$ improved slowly, but stiffness was noted for 24 to $48 \AA$

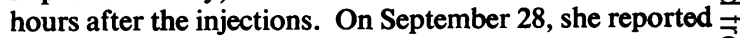

TABLE

PATHOLOGICAL DATA

\begin{tabular}{|c|c|c|c|c|c|c|c|c|c|}
\hline \multirow[b]{2}{*}{ Date } & \multirow[b]{2}{*}{$\begin{array}{l}\text { Red Cells } \\
\text { (Mil.l } \\
\text { c.mm.) }\end{array}$} & \multirow[b]{2}{*}{$\begin{array}{c}\text { Haemo- } \\
\text { globin } \\
\%\end{array}$} & \multirow[b]{2}{*}{\begin{tabular}{|c|} 
White \\
Cells \\
(c.mm.)
\end{tabular}} & \multirow[b]{2}{*}{$\begin{array}{l}\text { Packed } \\
\text { Cell } \\
\text { Volume } \\
\text { (ml.) }\end{array}$} & \multirow{2}{*}{$\begin{array}{c}\text { Erythrocyte } \\
\text { Sedimentation } \\
\text { Rate } \\
\text { (Wintrobe } \\
\text { mm./hr) }\end{array}$} & \multirow[b]{2}{*}{$\begin{array}{c}\text { Blood } \\
\text { Urea } \\
\text { (mg.l } \\
100 \mathrm{ml} .)\end{array}$} & \multirow[b]{2}{*}{$\begin{array}{l}\text { Plasma Protein } \\
(\mathrm{g} . / 100 \mathrm{ml} .)\end{array}$} & \multicolumn{2}{|r|}{ Urine } \\
\hline & & & & & & & & $\begin{array}{l}\text { Albumin- } \\
\text { uria }\end{array}$ & $\begin{array}{c}\text { Microscopy } \\
\text { (high-power field) }\end{array}$ \\
\hline $9 / 3 / 49$ & $3 \cdot 60$ & 72 & 5,500 & 35 & 55 & & . & Trace & $\begin{array}{l}15-20 \text { pus cells and odd red } \\
\text { cell; no casts or crystals. }\end{array}$ \\
\hline $28 / 9 / 49$ & & & & & & & & +++ & $\begin{array}{l}\text { 10-12 pus cells, odd red cell; } \\
\text { a few hyaline casts* }\end{array}$ \\
\hline $9 / 12 / 49$ & $4 \cdot 10$ & 80 & 9,200 & & & & 4 & $++t$ & $\begin{array}{l}\text { Numerous granular and hya- } \\
\text { line casts; } 3-5 \text { pus cells. }\end{array}$ \\
\hline $15 / 12 / 49$ & & & & & & 46 & $3.9\left\{\begin{array}{l}A=1.5 \\
G=2.4\end{array}\right.$ & & \\
\hline $30 / 12 / 49$ & & 86 & & & & 30 & & +++ & $\begin{array}{l}\text { Innumerable granular casts } \\
\text { and pus cells. }\end{array}$ \\
\hline $3 / 1 / 50$ & & 94 & & & & & $3 \cdot 5\left\{\begin{array}{l}A=1 \cdot 7 \\
G=1 \cdot 8\end{array}\right.$ & & \\
\hline $10 / 1 / 50$ & & & & & & 38 & & & \\
\hline $27 / 6 / 50$ & $2 \cdot 40$ & 47 & 9,000 & 21 & 74 & 170 & & ++++ & $\begin{array}{l}\text { Numerous hyaline and gran- } \\
\text { ular casts; many red and } \\
\text { white cells. }\end{array}$ \\
\hline $12 / 7 / 50$ & & & & & & & $4 \cdot 5\left\{\begin{array}{l}A=2 \cdot 1 \\
G=2 \cdot 4\end{array}\right.$ & & \\
\hline & & (1) & 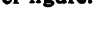 & & & 144 & & & \\
\hline
\end{tabular}


with slight puffiness of the face and swelling of both legs extending to the knees. Examination revealed no abnormalities apart from oedema, albuminuria, and cylindruria. The injections were discontinued; she was placed on a low-fluid, low-salt diet, and advised to rest as much as possible. On October 5 , she stated that she felt better; the puffiness of the face had diminished, but the ankles continued to swell if she walked. Rest in bed and a highprotein, low-salt diet were advised.

On December 8 she was admitted to the Cardiff Royal Infirmary with progressive oedema of the legs and ascites. Examination showed her general condition to be fairly good. The blood pressure was $160 / 100$, with no cardiac abnormalities. Bilateral pleural effusions and ascites were present. The liver and spleen were not enlarged. Marked oedema was present in the feet, legs, thighs, abdominal wall, and lumbo-sacral area of the back. The Wassermann reaction was negative. By December 12 the oedema had spread to the front of the chest and to the face. Acupuncture of both legs was performed on two occasions, several hundred ounces of fluid being withdrawn. The patient now felt much more comfortable, although the oedema had generally increased, and she was discharged from hospital on January 31, 1950. While in hospital her urinary output had never exceeded $26 \mathrm{oz}$. daily. It was considered that she was suffering from a nephrotic lesion due to sodium bismuth tartrate therapy.

She now came under the supervision of the first hospital again. During May, 1950, she was admitted on three occasions for paracentesis abdominis and acupuncture of legs-about $300 \mathrm{oz}$. being withdrawn each time. She was last admitted on June 24. Examination then showed marked anaemia, gross oedema of the face, legs, and abdominal wall, and marked ascites. The blood pressure was $180 / 115$. The heart was not enlarged. Numerous adventitial sounds were heard in all areas of the chest. Marked oedema of the whole body gradually developed. Paracentesis abdominis on July 11 and 16 produced about 12 pints of fluid each time. Pericarditis developed, her general condition deteriorated steadily, and she died on July 18, 1950.

\section{Discussion}

The pharmacological investigations of sodium bismuth tartrate and the bismuth compounds carried out by Longley, Clausen, and Tatum (1940) indicated the similarities rather than the differences between these compounds and suggested that bismuth compounds acted in a form common to all and not in the form of the compound injected. Subsequently Clausen, Longley, Green, and Tatum (1942) noted that bismuth preparations manifested their therapeutic activity as well as toxicity in direct proportion to their elemental bismuth content. Sollmann (1948) also pointed out that:

the close correlation of toxic and therapeutic action on intramuscular injection indicates that the potency in both respects is determined by the concentration of bismuth and not by the nature of the original compound.

The concentration of bismuth will, of course, depend on the rate of absorption and excretion. Sollmann, Cole, and Henderson (1933) found that the percentage urinary excretion (the main route) was nearly uniform for all bismuth compounds15 to 25 per cent. within 3 weeks. Sollmann (1948) later noted that about half of the retained bismuth was excreted in the first 3 weeks after administration was stopped, while the remainder was tenaciously retained.

The distribution of bismuth in the internal organs is of interest. According to Leonard (1928):

All investigators employing a variety of bismuth drugs and of analytical methods arrive at a uniform result-the kidneys contain the highest percentage of bismuth.

Oettingen (1930) noted similar results in man following parenteral administration. Histological lesions in the kidneys have also been recorded. Brown, Lucia, and Mills (1938) described destruction of the convoluted tubules in rabbits following intravenous administration of sodium bismuth tartrate.

Nephritis occurs among the clinical systemic toxic manifestations of bismuth therapy listed by Goodman and Gilman (1941). They commented that the accumulation of the element at the site of excretion favoured renal damage:

Nevertheless, as used clinically it rarely causes impairment of renal function or urinary evidence of parenchymatous damage.

Kolmer, Brown, and Rule (1939) pointed out that the kidney lesion was essentially nephrotic, and that the nephrotoxic effect was related not only to elemental bismuth, but to the rate of its dissociation, absorption, and excretion. Although deaths from renal toxic effects following therapy (for syphilis and other conditions) with various bismuth compounds have been described, no cases so far have appeared incriminating sodium bismuth tartrate in ordinary doses as the cause of fatal renal tubular lesions. Dowds (1936) reported three delayed deaths following subcutaneous sodium bismuth administration in gross over-doses (approximately 25, 13, and $25 \mathrm{gr}$.); two of these cases showed marked renal symptoms and autopsy revealed kidney damage.

The bismuth preparation used in the case here reported contained 1 gr. sodium bismuthyl tartrate B.P. in $1 \mathrm{ml}$. isotonic dextrose solution. Approximately 1 gr. of elemental bismuth was administered. Within 11 weeks of the initiation of therapy the patient developed oedema, heavy albuminuria, and 
cylindruria. Subsequently the full typical nephrotic syndrome became manifest, and, despite temporary improvement, nitrogen retention developed and uraemic features preceded death. Although sodium bismuth tartrate is generally safe, it has been established, as indicated above, that all bismuth compounds may be cumulative and toxic, the toxicity depending on the bismuth content. Equally clear is the liability of sodium bismuth tartrate and other compounds to produce renal damage. Despite the small total intramuscular dosage the drug would appear to be responsible for the renal damage in this case.

\section{Summary}

(1) A case of nephrotic syndrome is described in a 39-year-old female following the injection of 2.5 gr. sodium bismuth tartrate for rheumatoid arthritis.

(2) It is noted that bismuth compounds, probably acting in a form common to all, manifest their therapeutic activity and toxicity in proportion to their elemental bismuth content.

(3) The danger of cumulative effect is indicated.

(4) Amongst the toxic effects, renal damage, which may be fatal, as in this case, is emphasized.

I am indebted to Dr. Leonard Howells for permission to publish this case, and for helpful advice and criticism.

\section{REFERENCES}

Brown, J. W., Lucia, S. P., and Mills, E. S. (1938). J. Pharmacol., $63,292$.

Clausen, N. M., Longley, B. J., Green, R. E., and Tatum, A. L. (1942). Ibid., 76, 338

Dowds, J. H. (1936). Lancet, 2, 1039.

Goodman, L. (1948). Brit. med. J., 1, 978.

Goodman, L., and Gilman, A. (1941). "The Pharmacological Basis of Therapeutics." Macmillan, New York.
Kolmer, J. A., Brown, H., and Rule, A. M. (1939). Amer. J. Syph.

23, 7. S. (1928). J. Pharmacol., 34, 333.

Leonard, C. S. (1928). J. Pharmacol., 34, 333.
Longley, B. J., Clausen, N. M., and Tatum, A. L. (1940). Ibid.,
69, 294.

Martindale, W. (1943). “The Extra Pharmacopoeia," 22nd ed., vol. 2. Pharmaceutical Press, London.

Oettingen, W. F. von (1930). Physiol. Rev., 10, 221

Sollmann, T. (1948). "Manual of Pharmacology," 7 th ed. Saunders

Philadelphia. Chicago, 28, 615 .

Syndrome néphrotique apres traitement d'arthrite rhumatismale par le tartrate sodique de bismuth

\section{RÉSUMÉ}

(1) On décrit un cas de syndrome néphrotique chez $\overrightarrow{\vec{\omega}}$ une femme de 39 ans survenant après l'injection deळ

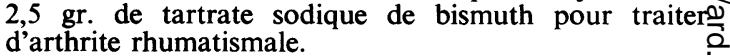

(2) On note que les composés de bismuth, doués tous probablement d'une action similaire, manifestent leur activité thérapeutique et leur toxicité en fonction de leur teneur en bismuth pur.

(3) On indique le danger de l'effet cumulatif.

(4) On souligne, parmi les effets toxiques, la lésiono rénale qui peut être mortelle, comme le montre le casdécrit.

Sindrome nefrótico después del tratamiento de la artritis reumatoide con el tartrato sódico de bismuto

\section{Sumario}

(1) Se describe un caso de síndrome nefrótico en una mujer de 39 años ocurriendo después de una inyección de 2,5 gr. de tartrato sódico de bismuto al tratar sus artritis reumatoide.

(2) Se nota que los compuestos de bismuto, todoš probablemente dotados de una acción similar, mani $\Omega$ festan su actividad terapéutica y su toxicidad en función de su tenor de bismuto puro.

(3) Se indica el peligro del efecto cumulativo.

(4) Se hace resaltar, entre los efectos tóxicos, la lesiónrenal que puede ser mortal, como en el caso descrite aquí. 